\title{
PELATIHAN PENGGUNAAN APLIKASI EDMODO DALAM MENUNJANG PROSES PEMBELAJARAN DI SMAN 1 CIOMAS
}

\author{
Fitri Aida Sari ${ }^{1,2}$ \\ ${ }^{1}$ Teknik Sipil, Universitas Banten Jaya, Jl. Syech Nawawi Albantani Serang Banten \\ ${ }^{2}$ Pendidikan Matematika, Universitas Pendidikan Indonesia, Jl. Dr. Setiabudi No.229, Isola, Kec. Sukasari, Kota \\ Bandung, Jawa Barat 40154 \\ Email: fitriaidasari@unbaja.ac.id
}

\begin{abstract}
Mastery of technology is one aspect that teachers and students must have. Learning that is not accompanied by using of technology, will make learning difficult to develop. Edmodo is a technologybased application that is accessed online and can help teachers carry out learning. Edmodo has various features such as creating online classes, arranging agendas, doing digital storage, even teachers can create quizzes, assignments or exams that teachers can design, such as national exams. The purpose of this community service program is to introduce students to what edmodo is and how to use it. The training was carried out by providing materials and tutorials on how to use edmodo. After that, students are welcome to practice using Edmodo and the presenters monitor the practice of the students. Based on interviews conducted with students related to training in the use of edmodo, it was concluded that students felt tremendous benefits from this training and hoped that technology-based learning, especially using edmodo, could be applied by teachers in their schools.
\end{abstract}

Keywords: Training; Edmodo; Technology; Learning; Online.

\begin{abstract}
ABSTRAK
Penguasaan teknologi merupakan salah satu aspek yang harus dimiliki oleh guru maupun siswa. Pembelajaran yang tidak diiringi oleh penggunaan teknologi didalamnya akan membuat pembelajaran tersebut sulit untuk dikembangkan. Edmodo merupakan salah satu aplikasi berbasis teknologi yang diakses secara online dan dapat membantu guru melaksanakan pembelajaran. Edmodo memiliki berbagai fitur seperti membuat kelas online, menyusun agenda, melakukan penyimpanan digital bahkan guru dapat membuat kuis, tugas maupun ujian yang dapat guru rancang seperti ujian nasional. Tujuan dari program pengabdian masyarakat ini adalah untuk memperkenalkan kepada siswa apa yang dimaksud dengan edmodo dan bagaimana cara menggunakannya. Pelatihan dilakukan dengan pemberian materi dan tutorial cara menggunakan edmodo. Setelah itu, siswa dipersilahkan melakukan praktek penggunaan edmodo dan pemateri memantau jalannya praktek yang dilakukan oleh siswa. Berdasarkan wawancara yang dilakukan kepada siswa terkait pelatihan penggunaan edmodo diperoleh kesimpulan bahwa siswa merasakan manfaat yang luar biasa dari pelatihan ini dan berharap pembelajaran berbasis teknologi khususnya dengan menggunakan edmodo dapat diterapkan oleh guru di sekolahnya.
\end{abstract}

Kata Kunci: Pelatihan; Edmodo; Teknologi; Pembelajaran; Daring.

\section{PENDAHULUAN}

Saat ini pemanfaatan teknologi mulai diterapkan di berbagai sektor mulai dari perekonoian, pertanian, perindustrian, bahkan pada sektor pendidikan (Subiyanto, Supriyat, \& Markamah, 2018). Teknologi merupakan salah satu aspek yang harus dikuasai oleh guru, siswa maupun setiap orang yang terlibat di dalam proses pembelajaran. Proses pembelajaran yang 
tidak diiringi oleh penggunaan teknologi didalamnya akan membuat pembelajaran tersebut sulit untuk dikembangkan. Teknologi mempermudah siswa untuk mengakses beragam sumber belajar sehingga pembelajaran yang awalnya hanya bersumber dari guru atau yang kita kenal dengan teacher center berubah menjadi student center. Teknologi memberikan ruang seluasluasnya bagi siswa untuk belajar. Setiap permasalahan yang ada dapat siswa temukan penyelesaiannya di google, bukan hanya itu saja, saat ini sudah banyak sekali buku elektronik yang dapat siswa download secara gratis sehingga siswa tidak perlu lagi mengeluarkan uang untuk membeli buku, karena mereka dengan mudahnya dapat menyimpan buku di komputernya bahkan ponsel pribadi yang dimiliki oleh masing-masing siswa.

Berdasarkan laporan yang disampaikan oleh We Are Social (2020) pada, Indonesia mengalami kenaikan jumlah pengguna internet sebesar $17 \%$ daripada tahun sebelumnya dengan total 175,4 juta pengguna. Besarnya penguna internet di Indonesia sebenarnya dapat kita artikan bahwa masyarakat sudah terbiasa menggunakan teknologi di dalam kehidupannya. Namun pada kenyataanya, penggunaan teknologi tersebut Sebagian besar hanya digunakan untuk mengakses media hiburan seperti facebook, instagram, youtube, twitter dan masih banyak lagi sosial media lainnya. Berdasarkan hasil wawancara yang dilakukan secara random kepada beberapa siswa diketahui bahwa teknologi yang biasanya digunakan di dalam proses pembelajaran hanyalah power point. Belum ada aplikasi yang guru gunakan untuk menunjang pembelajaran padahal banyak sekali aplikasi yang sengaja di rancang khusus untuk membantu siswa di dalam proses pembelajaran.

Bukan hanya pembelajaran, ujian nasional (UN) di Indonesia juga sudah dilaksanakan dengan berbasiskan komputer atau yang kita kenal dengan sebutan UNBK (Kemendikbud, 2020). Jika kita ingat-ingat kembali, dahulu proses pelaksanaan ujian nasional cukuplah panjang. Dimulai dengan pembuatan soal, menggandakan soal, lalu mendistribusikannya ke masing-masing sekolah dengan pengawasan yang cukup ketat. Namun dengan adanya teknologi ujian nasional saat ini hanya menggunakan komputer sebagai medianya sehingga dapat menghemat biaya untuk menggandakan soal ujian yang untuk satu mata pelajaran saja membutuhkan lebih dari 10 lembar kertas jika soal tersebut harus di cetak.

Pelaksanaan ujian nasional berbasis komputer tersebut membuat siswa harus membiasakan diri dalam mengoprasikan komputer, selain itu siswa juga harus terbiasa mengerjakan soal yang di sajikan secara online. Salah satu aplikasi yang dapat guru gunakan untuk membiasakan siswa mengerjakan soal yang disajikan mirip dengan pelaksanaan ujian nasional adalah edmodo. Edmodo merupakan salah satu aplikasi yang dapat membantu guru melaksanakan pembelajaran secara online. Tampilan edmodo mirip dengan facebook, sehingga secara sekilas jika ada seseorang yang tidak mengetahui tentang aplikasi edmodo mereka akan 
beranggapan bahwa aplikasi yang sedang kita akses atau kita gunakan adalah facebook. Kemiripan tampilan edmodo dengan facebook seharusnya dapat memberikan kemudahan bagi siswa untuk menggunakan edmodo di dalam proses pembelajaran. Edmodo menjadi salah satu pilihan sebagai aplikasi pendukung pembelajaran yang dpat guru gunkan karena pengoprasian edmodo tidak membutuhkan keterampilan khusus dan semua orang dapat mengaksesnya dengan hanya memiliki akun edmodo (Ainiyah, 2015).

Banyak sekali kelebihan yang ditawarkan oleh edmodo diantaranya: 1) guru dapat membuat banyak kelas yang berbada. Misalnya seorang guru matematika mengajar kelas XI sebanyak 10 kelas maka guru tersebut dapat membuat 10 kelas yang berbeda. Tiap kelas memiliki kode akses yang berbeda pula sehingga jika siswa ingin memasuki kelas, guru dapat membagikan kode untuk masuk ke kelasnya masing-masing; 2) guru dapat membuat simulasi ujian nasional secara online dan membiasakan siswa mengerjakan soal dengan bantuan media komputer; 3) guru dapat membagikan materi secara online sehingga tidak perlu menggunakan media penyimpanan eksternal seperti harddisk karena siswa dapat download dan membacanya kapanpun dan dimanapun; dan masih banyak lagi kelebihan yang diberikan edmodo dalam membantu proses pembelajaran.

Penggunaan edmodo di dalam proses pembelajaran sudah selayaknya diterapkan di sekolah sedini mungkin. Bukan hanya guru yang harus memahami bagaimana cara menggunakan aplikasi edmodo dengan baik dan benar namun siswa juga harus mamahami hal ini sehingga diperlukan suatu pelatihan kepada siswa terkait dengan bagaimana cara menggunakan aplikasi edmodo, mulai dari membuat akun, menggunakan kode kelas untuk masuk ke kelas yang sudah dipersiapkan oleh guru, mengakses materi yang diberikan, dan berbagai kemampuan yang perlu untuk siswa miliki ketika guru ingin menggunakan edmodo di dalam proses pembelajaran.

\section{METODE}

Pelatihan penggunaan aplikasi edmodo diselenggarakan di SMAN 1 Ciomas pada akhir tahun 2019 dimana pelaksanaan pelatihan masih dapat dilaksanakan secara tatap muka (belum terjadi penyebaran Covid-19 sehingga belum ada peraturan untuk melaksanakan pembelajaran secara online di Indonesia). Tahapan yang dilakukan dalam pelatihan penggunaan aplikasi edmodo diantaranya adalah 1) Pembekalan materi mengenai pentingnya menggunakan teknologi di dalam pembelajaran; 2) Memperkenalkan berbagai aplikasi yang dapat digunakan di dalam pembelajaran; 3) Demonstrasi penggunaan aplikasi edmodo, mulai dari cara membuat akun, masuk ke kelas menggunakan kode, cara mengirimkan tugas, cara berkomunikasi secara dua arah dengan guru dan lmasih banyak lagi; 3) Praktek pemakaian aplikasi edmodo, dimana 
pemateri mempersilahkan siswa secara satu persatu mencoba menggunakan aplikasi edmodo dengan menggunakan personal computer yang sudah pemateri siapkan.

\section{HASIL DAN PEMBAHASAN}

Pelatihan yang dilakukan terbagi menjadi beberapa tahap, dimulai dari penjelasan mengenai pentingnya teknologi untuk diterapkan di dalam proses pembelajaran, macam-macam aplikasi yang dapat digunakan di dalam pembelajaran, serta bagaimana cara menggunakan edmodo. Pada pelatihan ini siswa diberikan pelatihan penggunaan edmodo secara detail mulai dari cara mengakses edmodo secara online ataupun menginstalnya di handphone masingmasing siswa sampai dnegan cara penggunaan aplikasi edmodo itu sendiri. Penjelasan yang diberikan oleh pemateri adalah sebagai berikut:

1. Pengenalan Aplikasi Edmodo

Pada tahap ini dilakukan pengenalan secara umum apa itu edmodo. Pemateri menjelaskan bahwa edmodo adalah platform yang sengaja dikembangkan untuk guru dan siswa dalam rangka menunjang proses pembelajaran dengan mengedepankan kenyamanan pengguna. Guru dapat membagikan materi yang telah ia bahas di kelas dengan sangat mudah dan cepat, setelah guru membagikan materi tersebut, siswa dapat langsung mengakses materi yang diberikan sehingga waktu yang diperlukan untuk menyampaikan informasi dari guru ke siswa menjadi angat singkat. Siswa dan guru dapat menginstal edmodo di handphone masing-masing, namun jika mereka ingin mengaksesnya melalui laptop atau komputer cukup mengetik kata "edmodo" di google seperti Gambar 1. berikut ini.

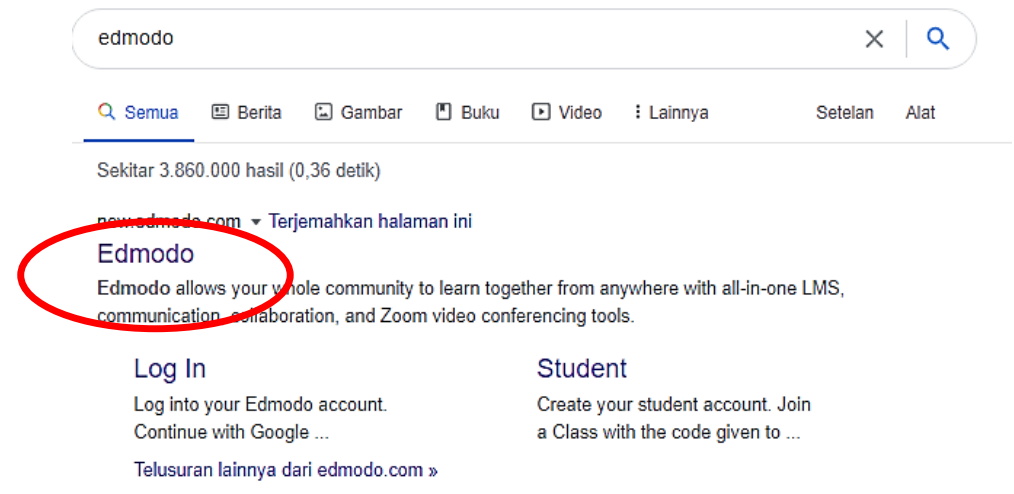

Gambar 1. Mengakses Edmodo melalui Google

Setelah muncul tampilan seperti Gambar 1, siswa dapat mengklik tulisan edmodo yang dilingkari tanda merah di atas. Kemudian guru dan siswa akan memasuki halaman depan untuk masuk (apabila sudah memiliki akun yang di daftarkan) atau mendaftar (apabila belum memiliki akun). Tampilan akan akan siswa lihat adalah sebagai berikut. 


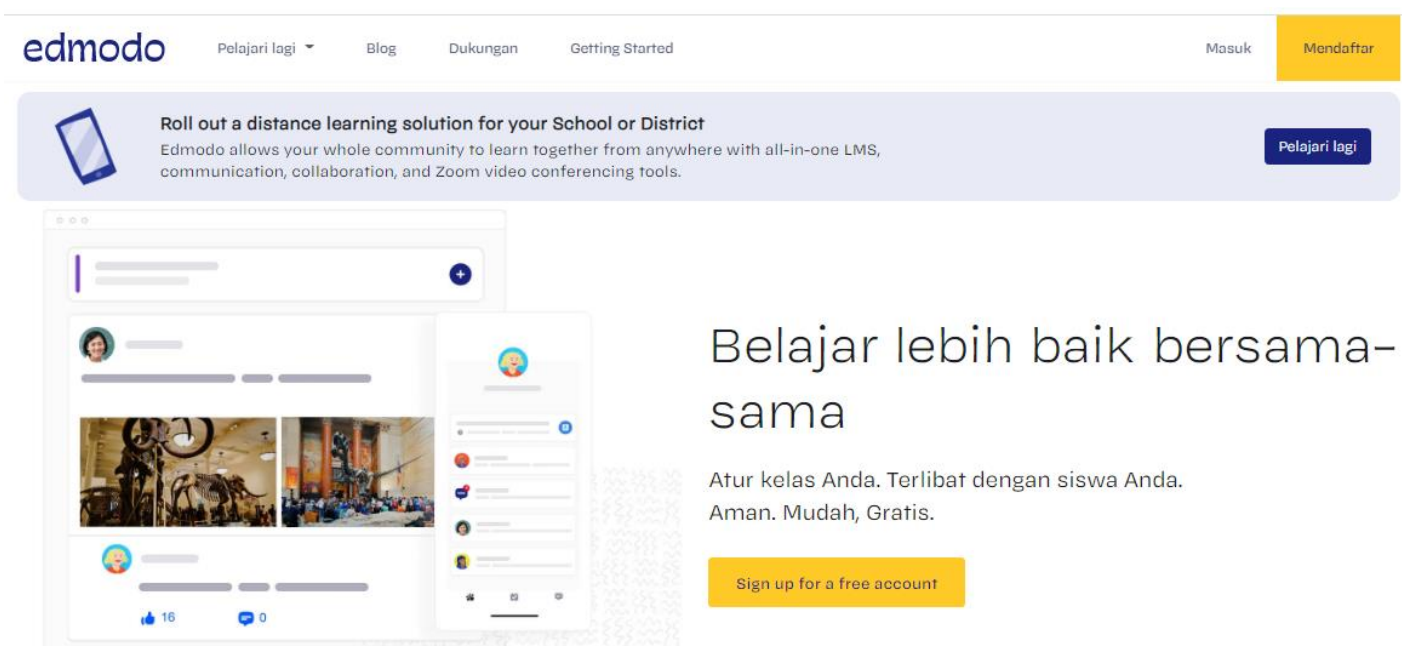

Gambar 2. Halaman Depan untuk Masuk dan Mendaftarkan Akun

2. Cara Membuat Akun Edmodo

Pada Tahap ini pemateri menjelaskan satu demi satu tahapan membuat akun edmodo. Di sebelah kanan atas pada Gambar 2 kita dapat melihat tulisan "mendaftar", siswa dapat menkiliknya apabila ingin membuat sebuah akun.

\section{edmodo}

$<$ Kembali

Choose an account

\begin{tabular}{|c|}
\hline $\begin{array}{l}\text { Teacher Account } \\
\text { For teachers, co-teachers, admins, coaches, club } \\
\text { advisors, instructional tech }\end{array}$ \\
\hline $\begin{array}{l}\text { Student Account } \\
\text { For students, class participants, club members, etc }\end{array}$ \\
\hline $\begin{array}{l}\text { Parent Account } \\
\text { For parents or guardians }\end{array}$ \\
\hline
\end{tabular}

Gambar 3. Tampilan Awal untuk Membuat Akun Edmodo

Pada tampilan yang muncul di Gambar 3, ada 3 pilihan akun yang dapat dipilih, teacher account dipilih jika ingin membuat akun guru, student account dipilih jika ingin membuat akun untuk siswa dan parent account dipilih jika ada orang tua/wali murid yang ingin memantau progress pekerjaan anaknya yang dilakukan pada aplikasi edmodo. Jadi jika guru menggunakan aplikasi edmodo di dalam proses pembelajaran maka hal ini juga memberikan 
kemudahan bagi orang tua siswa untuk ikut memantau dan mengawasi anaknya. Sasaran dalam pelatihan ini merupakan siswa sehingga pemateri memilih student account untuk dijelaskan. Tampilan yang akan muncul apabila kita memilih student account adalah sebagai berikut.

\begin{tabular}{l} 
edmodo \\
Create your student account \\
Join a Class with the code given to you by your teacher. After creating your \\
account, you can connect to your parent or guardian. \\
Class or School Code* \\
Nama Pengguna \\
\hline Surel (Opsional) \\
\hline Kata Sandi* \\
\hline Konfirmasi Kata Sandi* \\
\hline S Sign up with Microsoft \\
\hline OR \\
\hline Daftar dengan Google
\end{tabular}

Gambar 4. Data yang Harus Dilengkapi Siswa untuk Membuat Akun

Class or school code diperoleh melalui guru, jadi guru yang mengajarkan tiap bidang studi dapat membuat kelasnya masing-masing kemudian membagikan kode kelasnya ke siswa. Nama pengguna dapat siswa pilih secara bebas, yang terpenting nama yang siswa gunakan tidak sama dengan user edmodo lainnya. Apabila nama yang siswa gunakan sama atau sudah ada yang memiliki, maka akan ada pemberitahuan untuk mengganti dengan namayang lain. Untuk membuat nama pengguna, siswa diarahkan untuk membuat nama sesuai dengan nama siswa dan bukan menggunakan inisial atau nama panggilan lainnya sehingga memudahkan guru untuk melakukan penilaian. 


\section{edmodo}

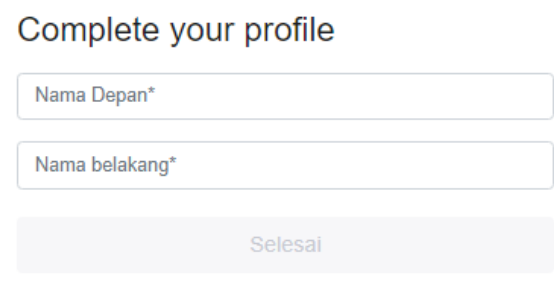

\section{Gambar 5. Melengkapi Profil Akun Edmodo}

Selanjutnya siswa akan diminta untuk melengkapi profil akun yang akan dibuat, data yang diminta meliputi nama depan dan nama belakang siswa. Jika data tersebut sudah siswa isi, tombol selesai akan berwarna biru dan dapat di klik oleh siswa, sepert contoh pada Gambar 6 berikut ini.

\section{edmodo}

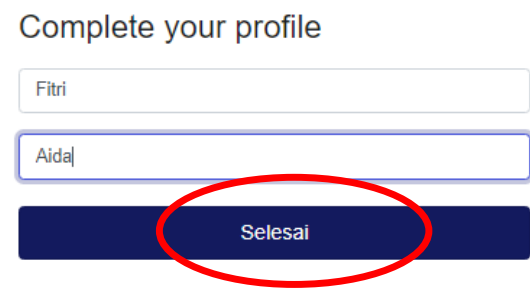

\section{Gambar 6. Tombol Selesai untuk Menyelesaikan Pembuatan Akun}

Langkah selanjutnya, siswa akan diminta untuk memasukkan nomor handphone atau alamat email orang tua. Siswa disarankan untuk memasukkan nomor handphone atau alamat email yang sebenar-benarnya dimiliki oleh orang tua dengan tujuan agar orang tua dapat memantau pekerjaan yang dikerjakan oleh siswa sehingga tidak ada tugas yang terlewat untuk dikerjakan oleh siswa. Namun langkah ini daat siswa lewatkan apabila siswa tidak mengisi data yang dibutuhkan. Guru sebaiknya memandu siswa untuk membuat akun edmodo ini sehingga ketika siswa membuat akun, guru dapat meminta siswa memasukkan nomor handphone milik orang tua dan tidak meleatkannya begitu saja. Pembelajaran akan berlangsung lebih baik apabila ada kolaborasi yang baik diantara guru dan orang tua siswa. Langkah ini dapat kita lihat pada Gambar 7. 


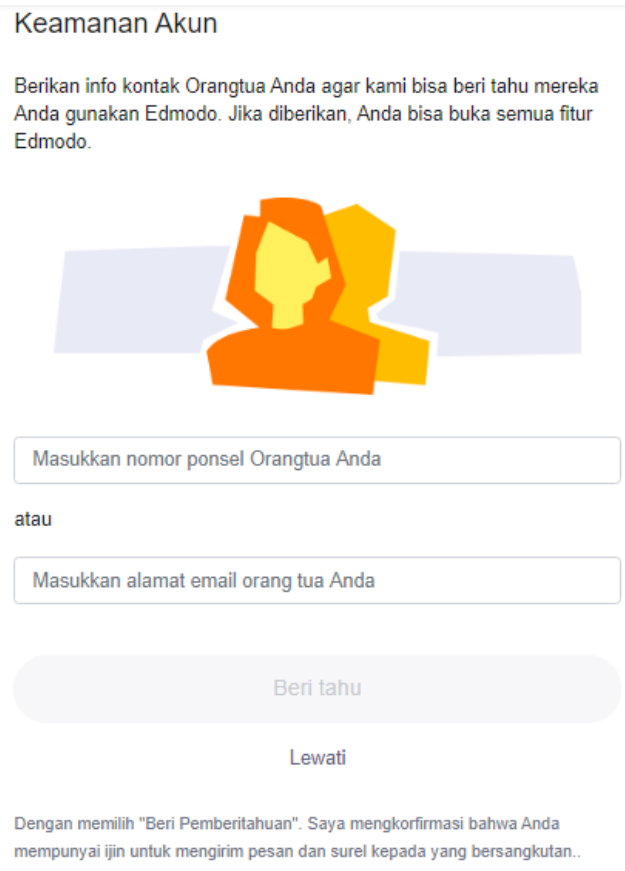

\section{Gambar 7. Memasukan Nomor Ponsel atau Email Orang Tua}

3. Pengenalan Tampilan Beranda Edmodo

Apabila siswa sudah memiliki akun, maka siswa dapat mengakses edmodo dengan log in menggunakan akun tersebut. Tampilan beranda edmodo yang muncul setelah siswa log in menggunakan akunnya adalah sebagai berikut.

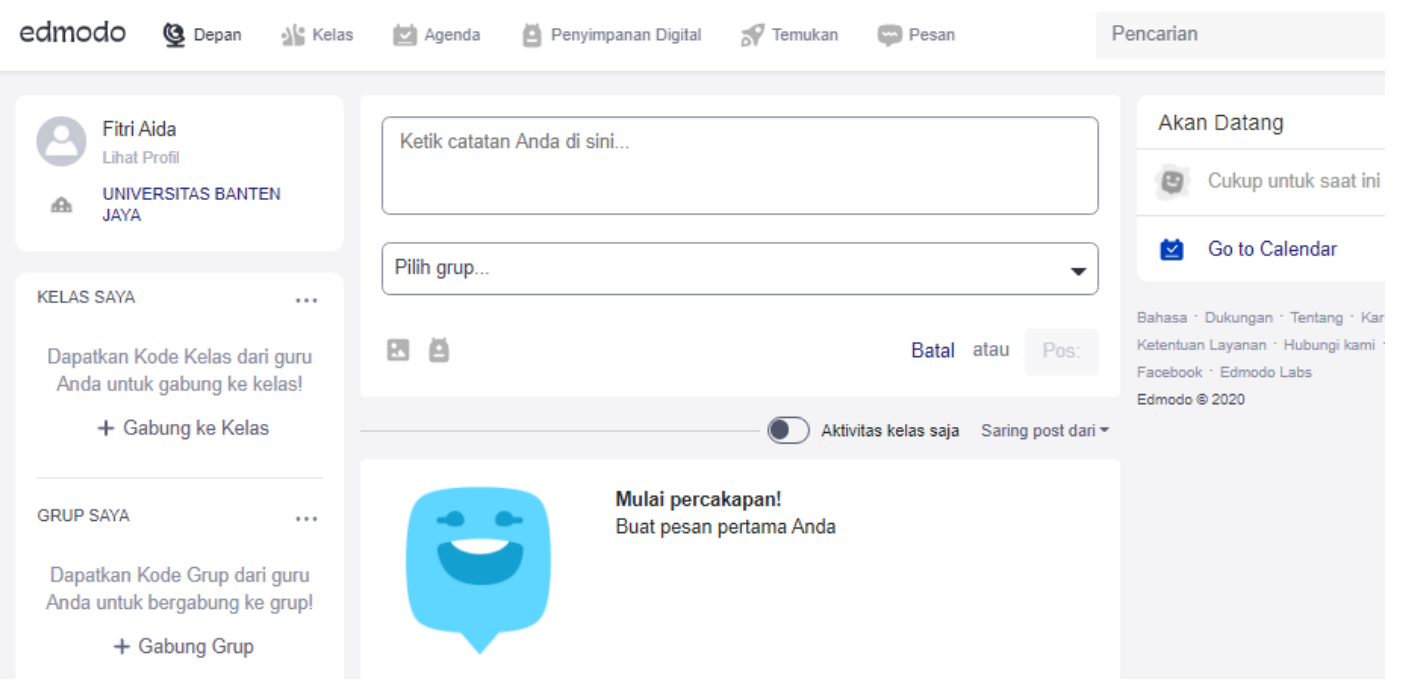

Gambar 8. Beranda Edmodo 


\section{Pengenalan Fitur Edmodo}

Banyak sekali fitur yang dapat kita akses pada edmodo. Jika kita mengamati Gambar 8, pada beranda bagian atas terdapat beberapa hal yang dapat kita akses diantaranya kelas, agenda, penyimpanan digital, temukan serta pesan. Fitur kelas digunakan untuk siswa mengakases kelas yang sudah ia masuki atau untuk bergabung ke dalam kelas yang baru melalui kode akses yang diberikan oleh guru. Jika kita membuat akun siswa, hanya ada pilihan untuk bergabung ke dalam suatu kelas, namu jika kita membuat akun techer maka pada fitur kelas tersebut akan ada option untuk membuat kelas atau bergabung ke dalam suatu kelas.

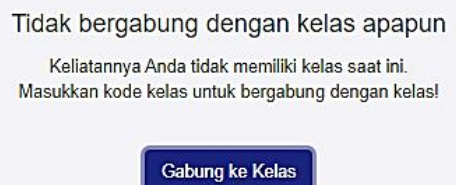

\section{Gambar 9. Akses Siswa untuk Bergabung dalam Kelas}

Tampilan untuk bergabung ke dalam suatu kelas akan siswa lihat seprti pada Gambar 9. Untuk bergabung siswa cukup klik gabung ke kelas dan memasukkan kode kelas yang berasal dari guru. Siswa dapat bergabung ke lebih dari satu kelas. Misalnya siswa kelas X suatu SMA Negeri memiliki 12 mata pelajaran yang ia pelajari maka siswa dapat bergabung ke dalam 12 kelas tersebut dengan kode kelas yang siswa dapatkan dari guru mata pelajaran.

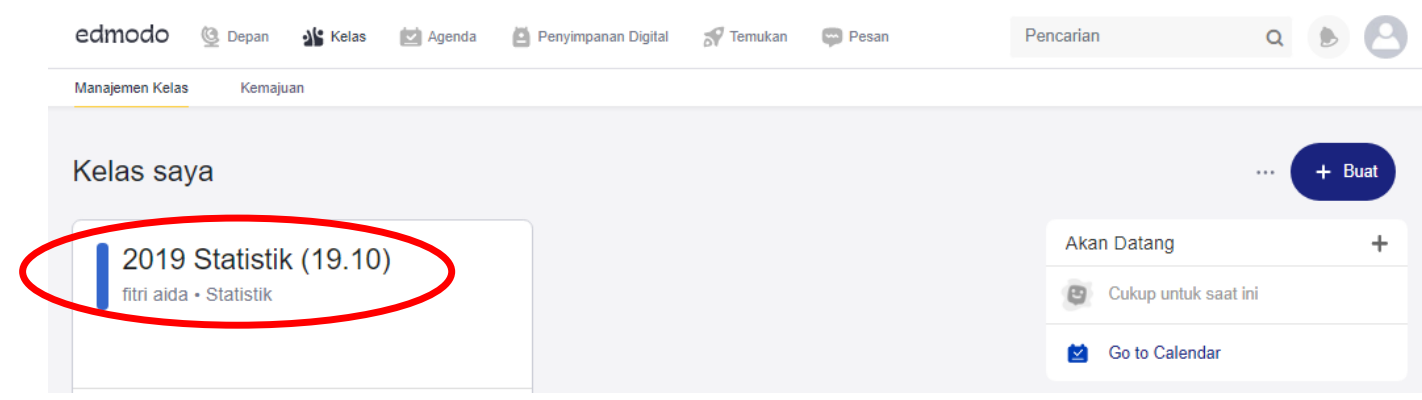

\section{Gambar 10. Tampilan Ketika Siswa Diterima Masuk Suatu Kelas}

Namun, siswa harus mendapat persetujuan guru untuk masuk ke dalam suatu kelas. Guru akan mendapatkan pemberitahuan persetujuan apabila siswa mengirimkan suaru request 
untuk masuk ke dalam kelasnya. Jika guru setuju maka siswa dapat bergabung dan melihat semua yang guru bagikan pada kelas tersebut. Sebagai contoh apabila guru sudah mengizinkan siswa untuk bergabung ke kelasnya dapat kita lihat pada Gambar 10. Fitur lainnya yang terdapat di halaman beranda dan dapat siswa gunakan adalah agenda. Agenda berisikan hal apa saja yang perlu kita kerjakan. Siswa dapat mengisi agendanya sendiri seprti halnya sedang mengisi buku catatan untuk mengingatkannya tugas apa saja yang perlu dikumpulkan. Tampilan agenda siswa pada edmodo dapat dilihat pada Gambar 11.

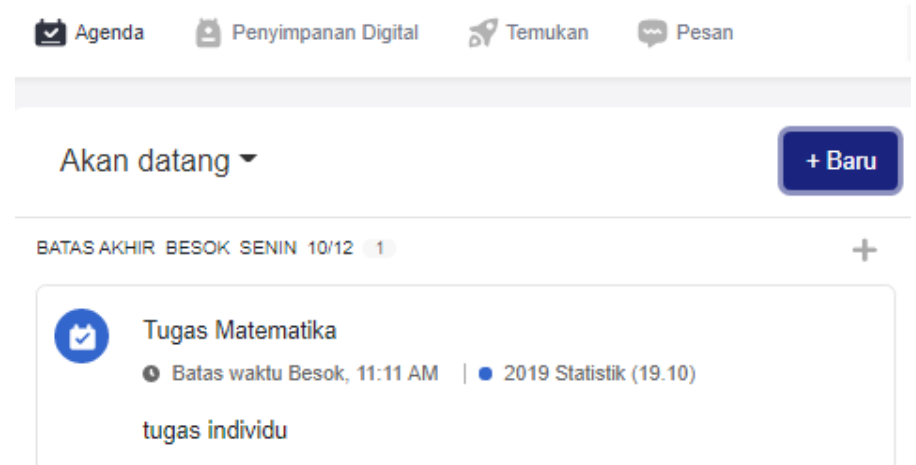

Gambar 11. Tampilan Agenda Siswa

Apabila siswa ingin membuat sebuah agenda baru, siswa cukup klik tulisan baru yang terletak di sebelah kanan atas. Kemudian siswa diminta untuk mengisikan beberapa informasi terkait judul tugas, kelas yang memberikan tugas (mata pelajaran yang diikuti), kategori tugas yang menyajikan 4 pilihan yaitu tugas, penugasan, kuis, dan acara (siswa dapat memilih salah satu kategori tersebut), keterangan, tanggal jatuh tempo, serta dapat disisipkan gambar atau file yang dibutuhkan (lihat Gambar 12).

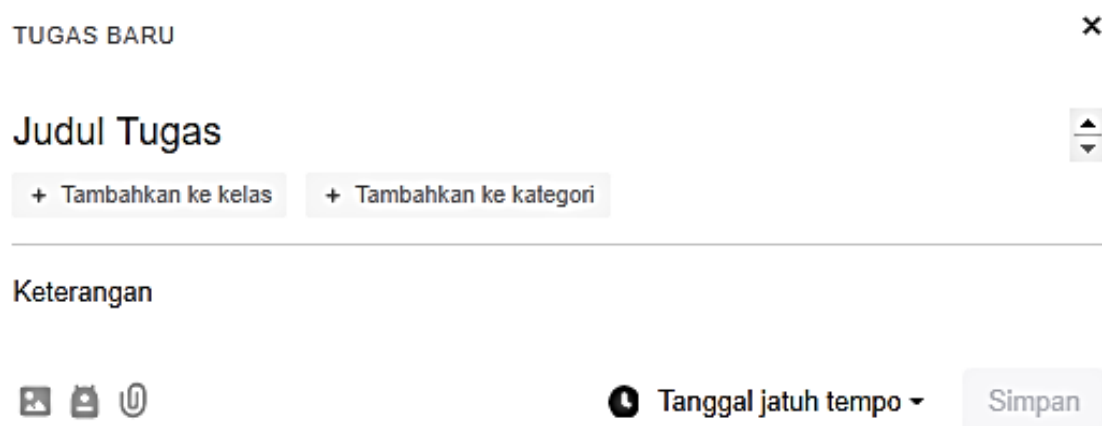

\section{Gambar 12. Membuat Agenda Baru}




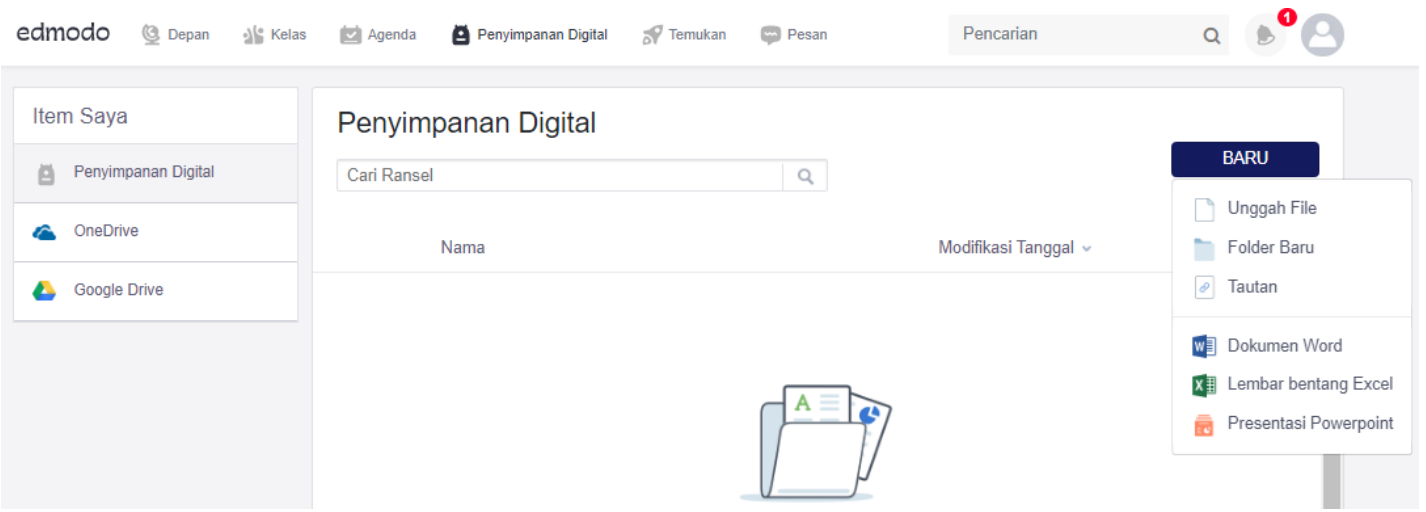

Gambar 13. Penyimpanan Digital

Untuk berkomunikasi secara pribadi dnegan guru ataupun siswa lainnya, edmodo menyediakan fitur pesan. Fitur pesan ini menghubungan dua orang sehingga dapat terjadi komukasi dua arah. Siswa dapat mengirimkan pesan kepada siapapun yang ada di kontaknya. Fitur ini dapat digunakan oleh siswa untuk menanyakan materi pembelajaran apabila yang guru jelaskan masih belum dipahami oleh siswa. Tampilan fitur pesan ini mirip sekali dengan fitur ketika kita ingin mengirimkan pesan kepada teman kita di facebook. Karena sudah banyak sekali siswa yang menggunakan facebook maka sudah pasti siswa akan dengan mudah menggunakan fitur pesan di edmodo. Tampilan fitur pesan pada edmodo ditunjukkan pada Gambar 14.

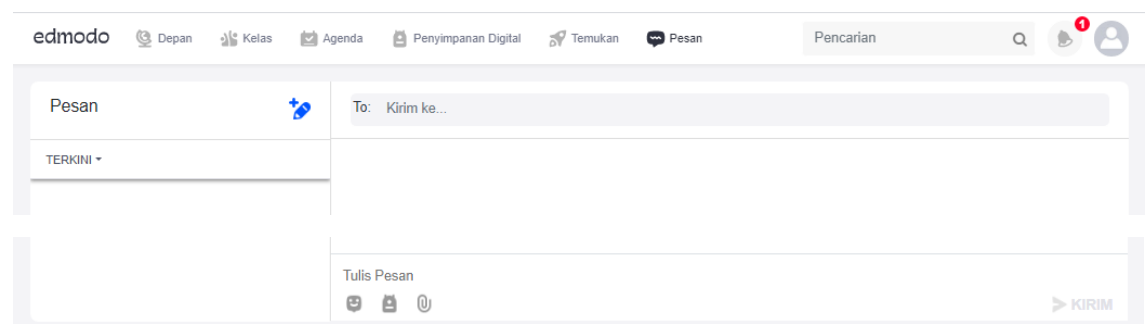

\section{Gambar 14. Pesan pada Aplikasi Edmodo}

\section{Siswa Mempraktekkan Penggunaan Edmodo}

Setelah pemateri selesai memberikan penjelasan, untuk memperkuat pemahaman siswa terhadap penggunaan edmodo maka siswa diberikan kesempatan untuk mempraktekkan secara langsung bagaimana cara menggunakan edmodo. Siswa mempraktekkan 1) Cara membuat akun edmodo; 2) Log in ke akun yang sudah mereka buat; 3) Mencoba semua fitur yang edmodo sediakan serta mencoba untuk mencoba mengerjakan soal yang sudah pemateri sediakan yang bentuk sajiannya mirip dengan sajian Ujian Nasional secara online menggunakan komputer. 
Pelatihan penggunaan edmodo di SMAN 1 Ciomas ditutup dengan penarikan kesimpulan secara bersama-sama terkait manfaat apa saja yang dirasakan oleh siswa setelah mendapatkan informasi baru tentang aplikasi edmodo. Siswa menyatakan banyak sekali manfaat yang dapat mereka peroleh apabila semua guru di sekolahnya menggunakan aplikasi tersebut di dalam proses pembelajaran. Siswa merasa senang dengan pelatihan yang diberikan dan berharap ada kelanjutan dari pelatihan yang sudah diberikan.
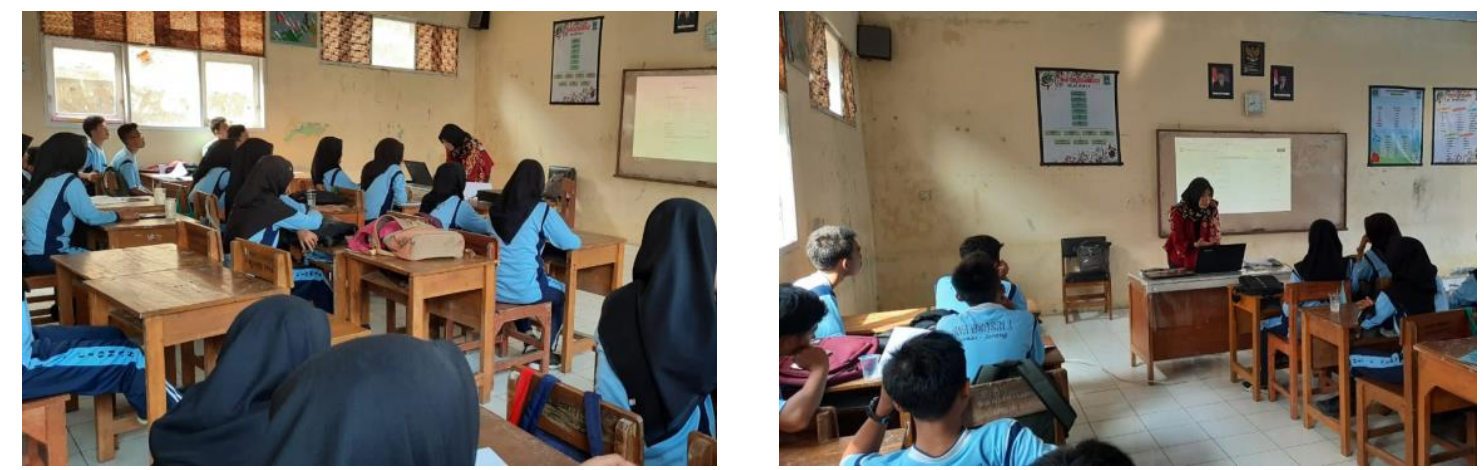

Gambar 15. Pelatihan Penggunaan Edmodo di SMAN 1 Ciomas

Manfaat yang dirasakan oleh siswa sejalan dengan pendapat yang dikemukakan oleh (Rulviana, 2018) bahwa edmodo menawarkan suatu kemudaan bagi pengajar baik guru maupun dosen. Apabila guru berhalangan hadir untuk mengajar, guru masih dapat memberikan materi pembelajaran yang dapat dipelajari oleh siswa, hal ini juga berlaku sebaliknya, jika siswa berhalangan hadir maka siswa tersebut tetap dapat mengetahui apa yang guru jelaskan di dalam kelas karena siswa dapat mengunduh materi tersebut jika guru mengunggahnya di kelas edmodo. Media pembelajaran seperti edmodo walauapun dilakukan secara online namun interaksi dan komunikasi antara siswa dan guru masih dapat terjadi layakna pembelajaran konvensional dimana siswa dapat berkomunikasi, berbagi dan berdiskusi baik dengan guru maupun teman sekelasnya terkait dnegan materi atau tugas yang diberikan (Putranti, 2016).

(Agustina \& Susanto, 2017) berpendapat bahwa guru memberikan persepsi yang positif terhadap pelatihan penggunaan edmodo karena edmodo dapat meningkatkan kompetensi guru dan memotivasi siswa untuk belajar. (Suriadhi \& Tastra, 2014) juga melakukan penelitian yang terkait pengembangan e-learning berbasis edmodo dan diperoleh hasil bahwa terdapat perbedaan yang signifikan terhadap hasil belajar siswa pada mata pelajaran Ilmu Pengetahuan Alam (IPA) antara siswa sebelum belajar menggunakan edmodo dan setelah siswa menggunakan edmodo. (Setyono, 2015) menyatakan berdasarkan hasil penelitian yang ia lakukan terdapat pengaruh yang signifikan dari penggunaan edmodo terhadap hasil belajar pada pembehasan mengenai pembuatan kurva-S. Belajar menggunakan aplikasi edmodo selain dapat 
meningkatkan prestasi siswa namun juga dapat meingkatan motivasi siswa untuk belajar karena kenyamanan yang siswa rasakan. Hal ini sejalan dengan pendapat (Hasanah, Wirawati \& Sari 2020) merasakan kenyamanan dan menyukai pembelajaran yang dilakukan jika pembelajaran yang dilakukan berbasiskan terknologi.

\section{KESIMPULAN}

Pelatihan penggunaan edmodo dibutuhkan bagi siswa untuk memperkenalkan teknologi yang dapat dipergunakan di dalam proses pembelajaran. Edmodo memberikan ruang belajar yang dapat di akses kapan saja dan dimana saja. Guru dapat membuat kelas maya dan berbagi materi atau bahan ajar pada kelas tersebut. Siswa dapat berdiskusi dengan guru dan temantemannya dengan memanfaatkan fitur pesan yang edmodo sediakan. Bukan hanya fitur pesan bahkan edmodo menyediakan penyimpanan digital sehingga siswa dapat menyimpan file materi atau tugas yang sudah dikerjakan dengan aman. Berbagai fitur penunang pembelajaran tersedia di edmodo dan dapat diakses secara gratis sehingga edmodo sangat disarankan untuk guru gunakan.

\section{DAFTAR PUSTAKA}

Agustina, N., \& Susanto, R. (2017). Persepsi Guru terhadap Pengembangan Profesionalisme melalui Pelatihan Media Pembelajaran Berbasis Edmodo. Prosiding Seminar Nasional $\begin{array}{llll}\text { Pendidikan Teknik } & \text { Informatika, } & \text { 44-48, }\end{array}$ http://eproceeding.undiksha.ac.id/index.php/senapati/article/download/1171/879

Ainiyah, Z. (2015). Penggunaan Edmodo sebagai Media Pembelajaran E-learning pada Mata Pelajaran Otomatisasi Perkantoran di SMKN 1 Surabaya. X(3), 373-379.

Hasanah, H., Wirawati, S \& Sari, F.A. (2020). Pengembangan Bahan Ajar Matematika Berbasis STEM pada Materi Bangun Ruang. Indonesian Journal of Learning Education and Counseling, 3(1), 91-100. https://doi.org/10.31960/ijolec.v3i1.582

Kementerian Pendidikan dan Kebudayaan. (2020). Ujian Nasional. Dapat diakses pada https://unbk.kemdikbud.go.id/\#tentang.

Putranti, N. (2016). Cara Membuat Media Pembelajaran Online menggunakan Edmodo. Jurnal Pendidikan Informatika Dan Sains, 2(2), 139-147.

Rulviana, V. (2018). Implementasi Media Edmodo dalam Mata Kuliah Pengembangan Kurikulum Sekolah Dasar. Refleksi Edukatika: Jurnal Ilmiah Kependidikan, 8(2). https://doi.org/10.24176/re.v8i2.2361

Subiyanto, S., Supriyati, I., \& Markamah, N. (2018). E-Learning Training using Edmodo based on Teachers of Smk NU Ungaran. Jurnal Abdimas, 22(1), 83-88. 
Suriadhi, G., Tastra, I. D. K., \& Suwatra, I. I. W. (2014). Pengembangan E-Learning berbasis Edmodo pada Mata Pelajaran IPA Kelas VIII di SMP Negeri 2 Singaraja. Jurnal Edutech Undiksha, 2(1).

We Are Social \& Hootsuite. (2020). Digital 2020: July Global Statshot - DataReportal - Global Digital Insights. DataReportal. https://datareportal.com/reports/digital-2020-july-globalstatshot

Setyono, E. Y. (2017). Pengaruh Penggunaan Media Jejaring Sosial Edmodo terhadap Hasil Belajar Mahasiswa pada Topik Pembuatan Kurva-s menggunakan Microsoft Excell. Soshum: Jurnal Sosial dan Humaniora, 5(1), 42. 